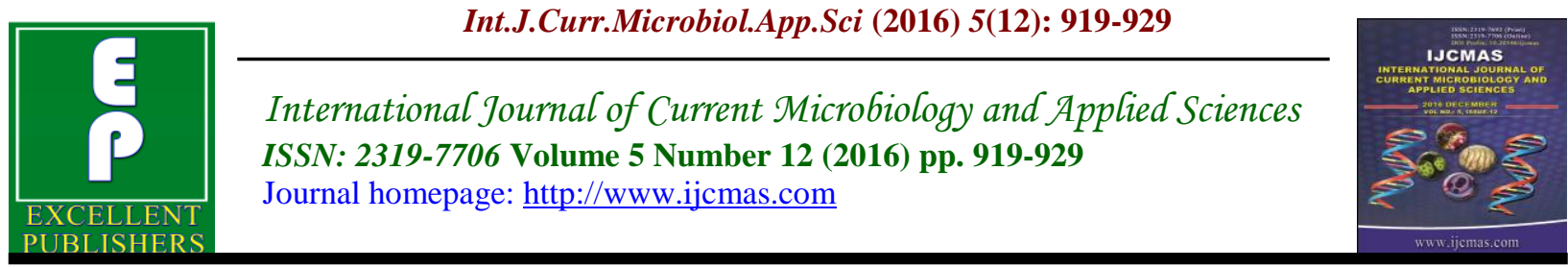

Original Research Article

http://dx.doi.org/10.20546/ijcmas.2016.512.100

\title{
Study on Fungi Associated with Tuber Vegetables during Storage in Markets of Telangana State, India
}

\author{
K. Brunda Devi ${ }^{1}$, Pavan Kumar Pindi ${ }^{2}$, D.S.R. Rajender Singh ${ }^{2}$ and B. Bhadraiah ${ }^{2}$ \\ ${ }^{1}$ Department of Botany, Osmania University, Hyderabad-500007, India \\ ${ }^{2}$ Department of Microbiology, Palamuru University, Mahabubnagar-509001, India \\ *Corresponding author
}

Keywords

Mycoflora, tuber vegetables, carrot, beet root, sweet potato and corm.

Article Info

Accepted:

25 November 2016 Available Online: 10 December 2016

\section{A B S T R A C T}

Fungi deteriorate the quality and quantity of the vegetables during transit and storage. An attempt was made to isolate and identify storage rot fungi associated with tuber vegetables collected from local markets of five districts in Telangana State, India. This study also reported the occurrence and distribution of fungi associated with four tuber vegetables viz., carrot, beetroot, sweet potato and corm during storage in all the five districts. Standard methods were followed to isolate and identify the fungi. A total of 41 fungal species belonging to 22 genera were observed. Among the four root vegetables, fungi were found predominantly on carrots while sweet potato had lesser dominance of fungi. Most predominant fungal species isolated from four tuber vegetables were recorded in Mahabubnagar followed by Rangareddy, Karimnagar, Nizamabad and Nalgonda. Fusarium species was found to be the most dominant fungi. Among the Fusarium sp., F. solani was the common fungus isolated from all four root vegetablesin all the five districts. Eight plant fungal species viz., Byssochlamys nivea, Conifera sp., Cunnighamella echinulata, Chaetomium mollicellum, Monilina fructicola, Monodictys fluctuate, Trichoderma hargianumand Trichothecium roseum were found for the first time to be associated with the tuber vegetables during the storage in Telangana state.This study underscores the implementation of post-harvest technology to prevent the economic loss due to fungal infestation of tuber vegetables during transit and storage at market level in Telangana state.

\section{Introduction}

Fruits and vegetables are important food commodities throughout the world. Fruits and vegetable are rich sources of vitamins, such as vitamin $\mathrm{C}$, folic acid (useful in synthesis of DNA), vitamin A, including minerals such as calcium and iron (Obetta et al., 2011). These also contain dietary fibres which add bulk to intestinal content and are useful in preventing constipation.
Fruits and vegetables have similar nutritive properties; $70 \%$ of their weight is water, $3.5 \%$ protein and about $1 \%$ fat (Obetta et al., 2011). Consumption of fruits and vegetables can help achieve or maintain a healthy body weight (National Institute of Research on Food and Nutrition Rome, Italy, 1998). Today, one of the main global challenges is how to ensure food security for a world 
growing population whilst ensuring longterm sustainable development. According to the FAO, food production will need to grow by $70 \%$ to feed world population which will reach 9 billion by 2050 (FAO/OECD, 2011). The pressure on demand for food is mainly due to the rapid growth of human population stressed the importance of fruits and vegetables in the human diet, especially in developing countries. India is the second and fourth largest producer of vegetables and fruits in the world, respectively.

Although adequate quantities of fruits and vegetables are produced, they become inadequate to feed huge population due to losses in the field as well as during storage. Generally, about $30 \%$ fruits and vegetables are rendered unfit for consumption owing to spoilage after harvesting. Microbes responsible for fruit and vegetable spoilage include bacteria and fungi. Spoilage microbes make fresh fruits and vegetables unfit for human consumption; by deteriorating their nutritional quality, normal texture and flavour.

In India, post-harvest loss of perishables is estimated to vary from 25 to $50 \%$ for fruits (Coursey and Booth, 1972) and 30-32\% for vegetables (Robinson, 1983), 12-32\% for root and stem tubers. In India, 20-30 \% of the produce is spoiled in the markets (FAO, 1977; FAO, 2002; Deka et al., 2006). India annually produces fruits and vegetables of the value of about Rs. 7000 crores and wastage may be of the order of Rs. 2100 crores. This is a huge loss of valuable food even when the minimum food requirement of the population is not met. Therefore, it is important not only to produce more, but also save what is grown at high cost. In order to find ways to reduce post-harvest loss, we need to conduct survey on factors such as mechanical, physiological, pathological and environmental that contributes to spoilage.
There is no published data on fungi which cause the post- harvest diseases connected with tuber vegetables from local markets of Telangana state, India. This study was aimed at isolation and identification of fungi, responsible for storage -rot associated with four root vegetables viz., carrot, beet root, sweet potato and corm, were collected at regular interval from local markets in five districts of Telangana during storage period. This study can also alert vegetables venders and public about the incidence of storage rot fungi in the markets of Telangana state, India.

\section{Materials and Methods}

\section{Sample collection and Isolation of fungi}

Sample collection and isolation of fungi was done by following the method reported by Odebode and Unachulwu (1997). Samples of rotted root vegetables namely carrot, beet root, sweet potato and corm were collected at regular interval into fresh polythene bags from five districts' local markets belonging to Telangana state, India. Samples were brought to the labs within 24 hours. Care was taken to avoid secondary infection by parasites.

Samples of rotted vegetables were surface sterilised with $70 \%$ alcohol for 1 minutes or $1 \%$ sodium hypochlorite solution for 2 minutes and washed twice with sterile distilled water and blotted dry with sterile filter paper. The infected parts were sliced aseptically into small cubes and placed onto potato dextrose agar (PDA). The plates were incubated at $28 \pm 2^{\circ} \mathrm{C}$ for 3 days. Petridishes were observed daily and colonies of fungi were chosen. The fungi were further purified using single spore technique, and then kept in a refrigerator on PDA slants in Mc cartney bottles (Gams et al., 1998 and Nagamani et al., 2006). 


\section{Identification of fungi}

The pure isolated fungi were identified using cultural and morphological features such as spore size, length, conidia formation, colony colour and diameter of colonies (Barnett and Hunter, 1972 (used for genus identification); Ellis, 1971 and 1976; Domsch et al., 1993; Moubasher 1993; Pitt and Hocking, 1997; Klich, 2002; Nagamani et al., 2006; Samson and Varga, 2007).

\section{Results and Discussion}

Fungi were isolated and identified from rotten tuber vegetables namely carrot, beet root, sweet potato and corm collected from local markets of Mahabubnagar, Nalgonda, Nizamabad, Karimnagar and Ranga Reddy districts during storage in Telangana state, India. Occurrence and distribution of fungi is presented in Table 1-5 and Fig. 1. Among the four tuber vegetables, carrot had the highest number of fungi (24), while Sweet potato had the lowest number of fungi (14) (Fig.1).

Out of 24 fungal species found to be associated with post-harvest samples of carrot, 23 fungal species were recorded from MBNR district followed by 20 from RR, 15 from NZB, 12 from NLD and 11 from KNR district (Table -1). Aspergillus niger, $F$. oxysporum, $F$. solani, $R$. arrhizus, $R$. solani, Rhizoctonia sp., S. sclerotiorum, S. rolfsii and Mycelia sterilia (black) were predominant in all the five districts compared to other fungi (Table-1). Less predominance was observedfor $A$. radiciana and $T$. hargianum. It is interestingly to note that the fungi viz., A. radicina, F. culmorum, F. oxysporum, M. phaseolina, M. fructicola, $M$. varians, $R$. arrhizus, $R$. stolonifer, $R$. carotae, $R$. solani S. minor, S. sclerotiorum, S. racemosum, $T$. harzianum and $T$. roseum are being reported as new host records to carrot.
A total of 18 fungal species were isolated from the beet root samples (Table -2). Out of which, 16, 8, 12, 11 and 16 fungal species were isolated from MBNR, NLG, NZB, KNR and RR districts, respectively. Among the 18 fungal spp. isolated, A. fumigatus, $F$. moniliforme, $F$. oxysporum, $F$. solani, $P$. funiculosum, R. arrhizus, $R$. stolonifer and $S$. rolfsii were predominantly occurring in the samples of all the five districts. Aspergillus flavus and $M$. varianswere restricted to NZB and MBNR, respectively. This is the first report on the isolation and identification of A. fumigatus, $F$. solani, M. varians, $R$. stolonifer, $S$. racemosum, T. harzianum and T. roseumas being associated with beet root from Telangana.

A total of 15 fungal species were isolated from rotten sweet potato samples(Table -3). Out of which 13 fungi were recorded in MBNR as well as in RR districts, 9 from NLG, 8 from NZB as well as KNR.Within the 14 fungal species isolated, A. terreus, $F$. oxysporum f. batatus, $F$. solani, $P$. decumbens and $R$. oryzae were observed to be predominant occurring in the samples of the all five districts while least predominance was found by $B$. nivea. Thielaviopsis paradoxa, M. fluctuata and $M$. phaseolina were recorded to be the new host records of sweet potato from Telangana.

A total of 21 fungal species were isolated from the corn samples (Table -4). Out of 21 fungi, 14, 12, 15 and 18 species were isolated from MBNR, NLGD, NZB, KNR and RR districts respectively Among the 21 fungal species isolated from corm samples $A$. niger, $F$. moniliforme, $F$. oxysporum, $F$. solani, G. candidum, M. phaseolina, $R$. arrhizus, S. sclerotiorum, $S$. rolfsii and $S$. racemosum were most frequently recorded from the samples of all the five districts. A. radicina was restricted to the samples of MBNR. Chaetomium mollicellum, $C$. 
echinulata, $M$. fragilis, $M$. varians, $S$. racemosum and $T$. harzianum are reported as new host findings.

Overall, a total of 41fungal species belonging to 22 genera were isolated from the spoiled samples of the carrot, Beet root, sweet potato and corm (elephant foot yam) from five districts (Table-5). Among the 22 genera, Fusarium sp. were found to be most dominant ones responsible for extensive damage of tuber vegetables in the local market of Telangana districts and followed by Aspergillus species. The samples of underground vegetables showed a high degree of fungal association and it was maximum in the samples of MBNR and next followed by those found in R.R district (fig.1). Out of 41 fungal species, 20 fungi such as $A$. niger, A. terreus, $A$. fumigatus, $F$. solani, $F$. oxysporum, $F$. oxysporum. f.batatus, F. moniliformae, G. candidum, M. phaseolina, Mycelia sterilia (black), $P$. funiculosum, $P$. decumbens, $R$. arrhizus, $R$. oryzae, $R$. stolonifer, Rhizoctonia solani, Rhizoctonia spp., S. rolfsii, S. sclerotiorum and $S$. recemosum were appeared predominantly in all five districts.

Fuasirium sp. were found to be most dominant fungi and next followed by Aspergillus sp.(Table 5).Among the all Fuasirium sp., Fusarium solani was the most common and frequently isolated fungus associated with all four tuber vegetables in all five districts.(Table 1-4). Eight fungi namely,Byssochlamys nivea, Cunnighamella echinulata, Chaetomium mollicellum, Monilina fructicola, Monodictys fluctuata, Trichoderma harzianum and Trichothecium roseum were recorded as new fungal species for the first time from the Telangana region (Table 5). The study also clearly indicated that the loss of tuber vegetables during storage is due to predominance of fungi.
Under the environment of this study, carrot had highest number of fungal species while in the sweet potato least number of fungi were recorded. Among the four tuber vegetables carrot showed high number of fungi due to its high sugar content and nutrients (Odebode and Unachulwu, 1997; Obetta et al., 2011). Least frequency of fungi on sweet potato is thought to be due to its high phenol content and wound cork formation (Bweimer and Harter, 1921; Madhukar and Reddy, 1991; Amusa et al., 2006 and Sarkar, 2009). Phenols are transported from healthy part of sweet potato to infection site of sweet potato. This could give resistance of the host towards pathogens (Madhukar and Reddy, 1991; Amusa et al., 2006 and Sarkar, 2009).

Fusarium species were reported to be most dominant fungi and followed by Aspergillus species. Among the Fusarium species, Fusarium solani was the most frequently isolated fungus and it was commonly associated with the all four root vegetables in all five districts of Telangana than other fungi. This might be due to either strong soil borne nature of the fungus or its high amount of conidia and chlamido spores in the market atmosphere and suitable environmental conditions for its growth in Telangana markets.

Highest frequency of fungi was recorded in Mahabubnagar, followed by Ranga Reddy. This might be owing to improper storage conditions and lack of knowledge about post-harvest handling techniques to the farmers and vegetable venders at field and markets, respectively. MBNR is poor district at an economical and educational level. People don't have awareness of post-harvest technology to keep vegetables fresh. This might be one of the reasons for having highest fungi in MBNR. 
Table.1 Occurrence and distribution of Fungal isolates from the post-harvest samples of rotten carrot in Mahabubnagar (MBNR), Nalgonda (NLG), Nizamabad (NZB), Karimnagar (KMNR) and Ranga reddy (RR) districts of Telangana

\begin{tabular}{|c|c|c|c|c|c|c|}
\hline S.NO & Fungi & MBNR & NLG & NZB & KNR & R.R \\
\hline 1 & *Alternaria radicina Meir Drech. \& Eddy & + & - & - & - & - \\
\hline 2 & Aspergillus flavus Link & + & - & + & - & - \\
\hline 3 & Aspergillus nigervan Tieghem & + & + & + & + & + \\
\hline 4 & Aspergillus terreus Thom & - & - & + & - & + \\
\hline 5 & *Fusarium culmorum (W.G. Smith) Saccardo & + & - & + & - & - \\
\hline 6 & *Fusarium oxysporum Schl. ex Fr. & + & + & + & + & + \\
\hline 7 & Fusarium solani (Martius) Sacc. & + & + & + & + & + \\
\hline 8 & Geotrichum candidum Link & + & - & - & - & + \\
\hline 9 & Macrophomina phaseolina* (Tassi) Goid. & + & + & + & - & + \\
\hline 10 & *Monilia fructicola (Winter) Honey & + & - & - & - & + \\
\hline 11 & *Mucor varians Povah & + & - & - & + & + \\
\hline 12 & *Rhizopus arrhizus A. Fischer & + & + & + & + & + \\
\hline 13 & Rhizopus oryzae Went \& Prins. Geerl. & + & - & + & + & + \\
\hline 14 & *Rhizopus stolonifer Ehr. ex Fr. & + & - & - & - & + \\
\hline 15 & *Rhizoctonia carotae Rader. & + & + & - & - & + \\
\hline 16 & *Rhizoctonia solani Kuhn & + & + & + & + & + \\
\hline 17 & Rhizoctonia sp. & + & + & + & + & + \\
\hline 18 & *Sclerotinia minor Jagger & + & - & + & - & + \\
\hline 19 & *Sclerotinia sclerotiorum (Lib.) Bary & + & + & + & + & + \\
\hline 20 & Sclerotium rolfsii Sacc. & + & + & + & + & + \\
\hline 21 & *Syncephalastrum racemosum Cohn ex J. Schrot. & + & - & - & - & + \\
\hline 22 & *Trichoderma harzianum Rifai & + & - & - & - & - \\
\hline 23 & * Trichothecium roseum Link & + & - & - & - & + \\
\hline \multirow[t]{2}{*}{24} & Mycelia sterilia (black) & + & + & + & + & + \\
\hline & Total & 23 & 12 & 15 & 11 & 20 \\
\hline
\end{tabular}

* = New host records

MBNR = Mahabubnagar $; \quad$ NLG = Nalgonda $; \quad$ NZB $=$ Nizamabad $; \quad$ KNR $=$ Karimnagar $; \mathbf{R R}=$ Ranga Reddy district $.(-)=$ Absent $(+)=$ present 
Table.2 Occurrence and distribution of Fungal isolates from the post-harvest rotten samples of rotten beet root in Mahabubnagar (MBNR), Nalgonda (NLG), Nizamabad (NZB), Karimnagar (KMNR) and Ranga reddy (RR) districts of Telangana

\begin{tabular}{llccccc}
\hline S. No & Fungi & MBNR & NLG & NZB & KNR & RR \\
\hline 1 & Aspergillus flavus Link & - & - & + & - & - \\
2 & *Aspergillus fumigatus (Fresenius) & + & + & + & + & + \\
3 & Aspergillus niger van Tieghem & + & + & + & - & + \\
4 & Fusarium dimerum (Penzig) & - & - & - & + & + \\
5 & Fusarium equiseti (Corda) Saccardo & + & - & - & + & + \\
6 & Fusarium moniliforme Sheldon & + & + & + & + & + \\
7 & Fusarium oxysporum Schl. ex Fr. & + & + & + & + & + \\
8 & *Fusarium solani (Martius) Sacc. & + & + & + & + & + \\
9 & Geotrichum candidum Link & + & - & - & - & + \\
10 & *Mucor varians Povah & + & - & - & - & - \\
11 & Penicillium funiculosum (Thom) & + & + & + & + & + \\
12 & Rhizopus arrhizus Fischer & + & + & + & + & + \\
13 & *Rhizopus stolonifer Ehr. ex Fr. & + & + & + & + & + \\
14 & Sclerotium rolfsii Sacc.(Athelia) & + & + & + & + & + \\
15 & *Syncephalastrum racemosum Cohn ex J. Schrot. & + & - & + & - & + \\
16 & *Trichoderma harzianum Rifai & + & - & - & - & + \\
17 & *Trichothecium roseum Link & + & - & - & - & + \\
18 & Mycelia sterilia (white) & + & - & + & + & + \\
\hline & Total & $\mathbf{1 6}$ & $\mathbf{8}$ & $\mathbf{1 2}$ & $\mathbf{1 1}$ & $\mathbf{1 6}$ \\
\hline
\end{tabular}

* = New host records(New fungi on carrot from Telangana region).

MBNR = Mahabubnagar $; \quad$ NLG $=$ Nalgonda $; \quad$ NZB $=$ Nizamabad $; \quad$ KNR $=$ Karimnagar $; \quad \mathbf{R R}=$ Ranga Reddy district. $(-)=$ Absent $(+)=$ present 
Table.3 Occurrence and distribution of fungal isolates fromthe post-harvest samples of rotten sweet potato inMahabubnagar (MBNR), Nalgonda (NLG), Nizamabad (NZB), Karimnagar (KMNR) and Ranga reddy (RR) districts of Telangana

\begin{tabular}{|c|c|c|c|c|c|c|}
\hline S. NO & Fungi & MBNR & NLG & NZB & KNR & $\mathrm{RR}$ \\
\hline 1 & Aspergillus flavus Link & + & - & + & - & + \\
\hline 2 & Aspergillus terreus Thom & + & + & + & + & + \\
\hline 3 & Botryodiplodia theobromae Pat. & + & + & - & - & + \\
\hline 4 & Byssoclamys nivea Westling & + & - & - & - & - \\
\hline 5 & Fusarium moniliforme Sheldon & + & + & - & - & + \\
\hline 6 & $\begin{array}{l}\text { Fusarium oxysporum. } f \text {. batatus (Schl. ex } \\
\text { Fr.) e. Anyd. Et Hans. }\end{array}$ & + & + & + & + & + \\
\hline 7 & Fusarium pallidoroseum (Cooke) Sacc. & - & - & + & + & - \\
\hline 8 & Fusarium solani (Martius) Sacc. & + & + & + & + & + \\
\hline 9 & *Macrophomina phaseolina (Tassi) Goid. & - & + & + & - & + \\
\hline 10 & *Monodictys fluctuata (Tandon \& Bilgrami) & + & - & - & - & + \\
\hline 11 & Mucor varians Povah & + & - & - & - & + \\
\hline 12 & Penicillium decumbens Thom & + & + & + & + & + \\
\hline 13 & Rhizopus oryzae Fischer & + & + & + & + & + \\
\hline 14 & $\begin{array}{l}\text { Thielaviopsis paradoxa (De Seynes) Hohn. } \\
\text { (Ceratocystis paradoxa)*(Dade) C. Moreau }\end{array}$ & + & + & - & + & + \\
\hline \multirow[t]{2}{*}{15} & * Mycelia sterilia(black) & + & - & - & + & + \\
\hline & Total & 13 & 9 & 8 & 8 & 13 \\
\hline
\end{tabular}

* = New host records

MBNR = Mahabubnaga

$\operatorname{Absent}(+)=$ present
NLG = Nalgonda; $\quad$ NZB = Nizamabad;
$\mathbf{K N R}=$ Karimnagar; $\mathbf{R R}=$ Ranga Reddy district. $(-)=$ 
Table.4 Occurrence and distribution of fungal isolates from the post-harvest samples of rotten corm in Mahabubnagar (MBNR), Nalgonda (NLG), Nizamabad (NZB), Karimnagar (KMNR) and Ranga reddy (RR) districts of Telangana

\begin{tabular}{|c|c|c|c|c|c|c|}
\hline S. No & Fungus & MBNR & NLG & NZB & KNR & RR \\
\hline 1 & Alternaria radicina Meir Drech. \& Eddy & + & - & - & - & - \\
\hline 2 & Aspergillus flavus Link & + & - & - & + & + \\
\hline 3 & Aspergillus niger van Tieghem & + & + & + & + & + \\
\hline 4 & Botryodiplodia theobromae Pat. & + & + & - & - & + \\
\hline 5 & *Chaetomium mollicellum L.M. Ames & + & + & - & - & + \\
\hline 6 & *Cunninghamella echinulata Thaxter & + & - & - & - & + \\
\hline 7 & Fusarium moniliformeSheldon & + & + & + & + & + \\
\hline 8 & Fusarium oxysporumSchl. ex Fr. & + & + & + & + & + \\
\hline 9 & Fusarium solani(Mart.) Sacc. & + & + & + & + & + \\
\hline 10 & Geotrichum candidumLink & + & + & + & + & + \\
\hline 11 & Macrophomina phaseolina(Tassi) Goid. & + & + & + & + & + \\
\hline 12 & *Mucor fragilis Bainier & - & - & - & + & + \\
\hline 13 & *Mucor varians Povah & + & - & - & + & + \\
\hline 14 & Penicillium decumbens Thom & + & - & + & - & - \\
\hline 15 & Rhizopus arrhizusFischer & + & + & + & + & + \\
\hline 16 & Rhizoctonia solani Kuhn & + & + & - & + & + \\
\hline 17 & Sclerotinia sclerotiorum(Lib.) Bary & + & + & + & + & + \\
\hline 18 & Sclerotium rolfsii Sacc. & + & + & + & + & + \\
\hline 19 & Syncephalastrum racemosum* Cohn ex J. Schrot. & + & + & + & + & + \\
\hline 20 & *Trichoderma harzianum Rifai & + & - & + & + & - \\
\hline \multirow[t]{2}{*}{21} & Mycelia sterilia (white) & + & + & - & - & + \\
\hline & Total & 20 & 14 & 12 & 15 & 18 \\
\hline
\end{tabular}

* = New host records

MBNR = Mahabubnagar $; \quad$ NLG = Nalgonda $; \quad \mathbf{N Z B}=$ Nizamabad $; \quad$ KNR $=$ Karimnagar $; \mathbf{R R}=$ Ranga Reddy district. $-=\mathrm{absent}+=$ present 
Table.5 Total number of various fungal species belonging to 23 genera in four underground vegetables collected from five districts of Telangana

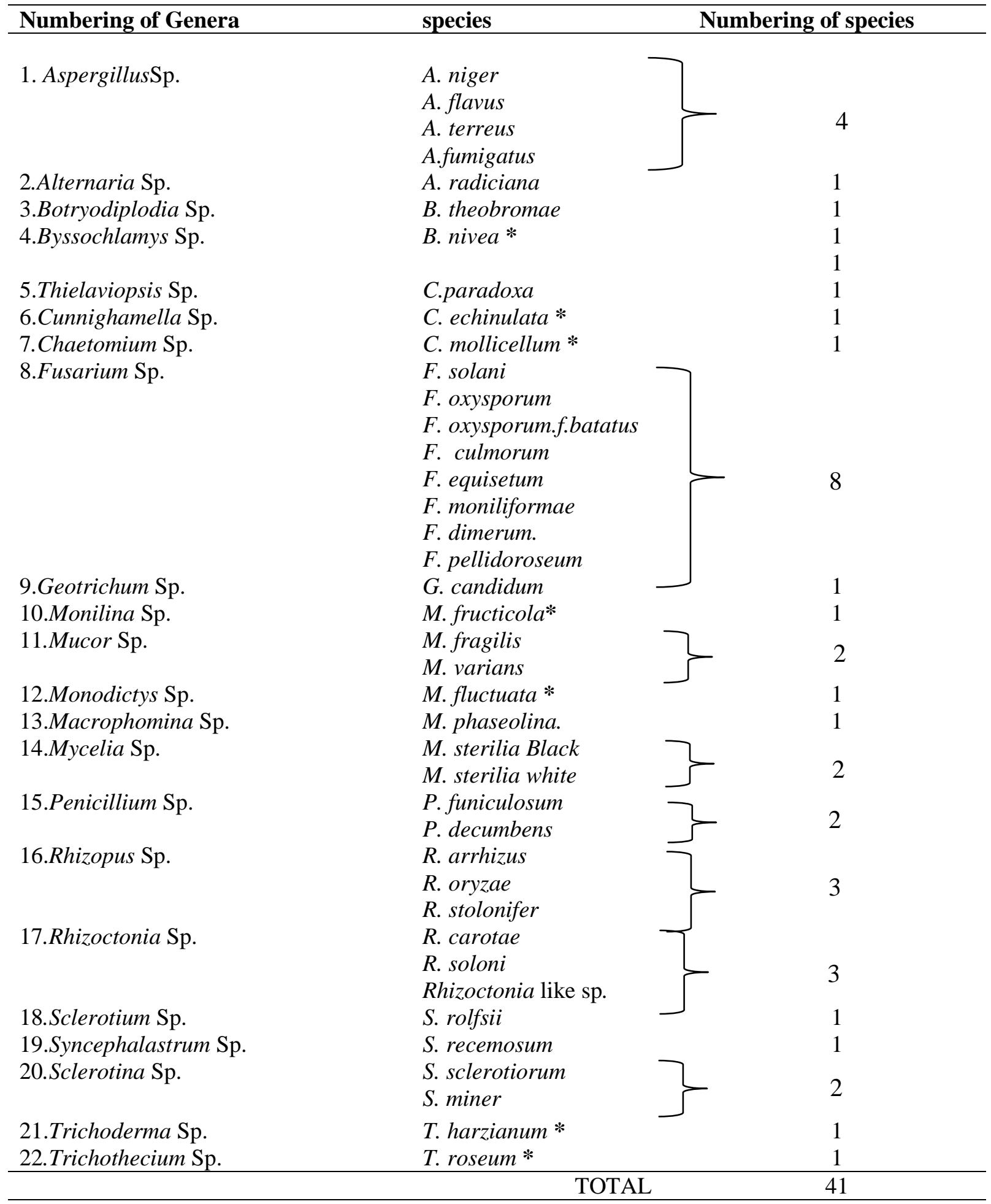

*= New fungi were identified for the first time from Telangana region 
Fig.1 Number of fungi recorded from post-harvest samples of rotten carrot, beet root, sweet potato and corm collectedfrom MBNR, NLG, NZB, KMR and R.R districts of Telangana

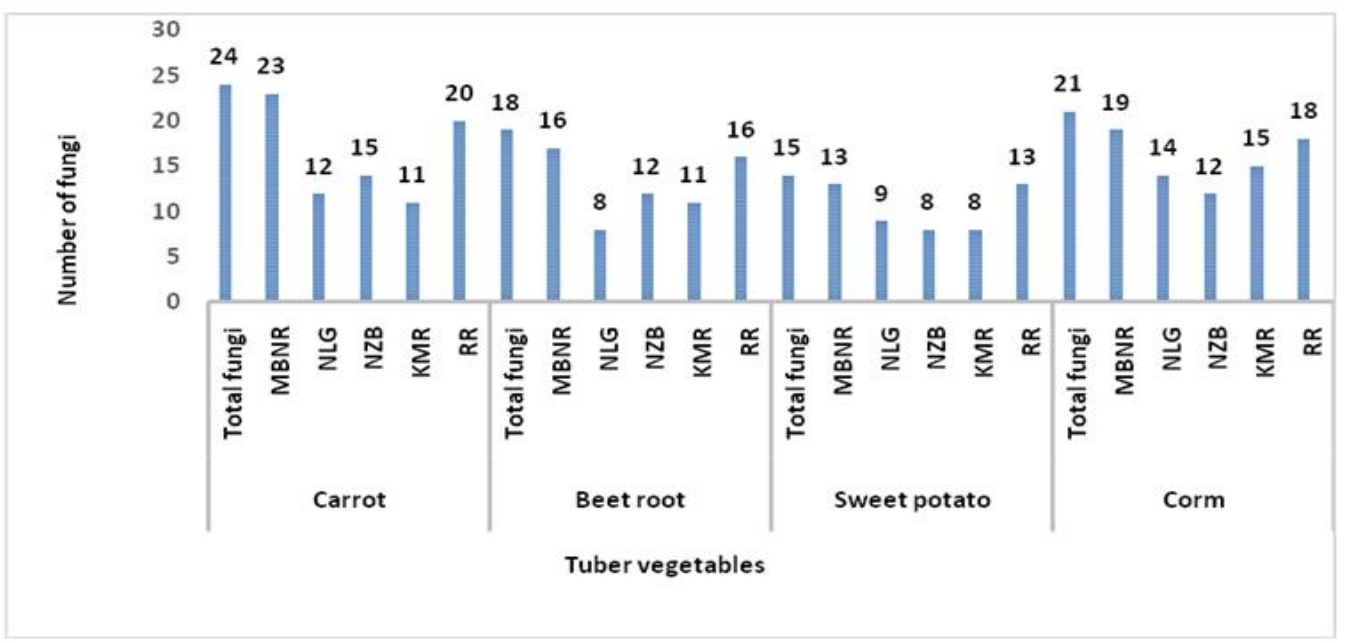

Of the 41 fungi, $F$. solani appeared throughout sampled areas in Telangana as well as in all four root vegetables. Therefore, Fusarium solani was the most frequently isolated fungus than other fungi. This could be due to either strong soil borne nature of the fungus and its high production of conidia and chlamidospores or suitable environmental conditions of Telangana markets for its growth. Similar finding are reported by Thakur in 1966. He surveyed Delhi Markets for fungal diseases of fruits and vegetables and found Fusarium Spp., and Rhizopus arrhizus to be the major pathogens and Aspergillus spp., and Penicillium to be minor pathogens.

The results of this study are in agreement with the findings of other researchers (Usharani, 1982) encountered that pre and post -harvest diseases of some underground vegetables and its associated fungi during storage in the surroundings of Hyderabad. The pre-dominance of these fungi which cause severe deterioration of produce is due to poor storage conditions, high moisture and other related factors. The poor postharvest technology in the transport system and markets has supported high disease incidence by fungal pathogens. In conclusion, the aim of this work was to isolate and identify the specific fungi associated with rotten root vegetables from five districts of Telangana. This study has provided useful information about the incidence of fungi associated with tuber vegetables in the district local markets of Telangana State, India and feasibility of post-harvest loss. Therefore, urgent attention is required to implement post-harvest handling technology in order to increase fresh vegetable supply and national economy.

\section{References}

Amusa, N.A., Ashaye, O.A., Amadi, J.A. and Oladapo, O. 2006. Guava fruit anthracnose and the effects on its nutritional and market valuses in Ibudan, Nigeria. J. Appl Sci., 6: 539-542.

Barnett, H.L. and Hunter, B.B. 1972. Illustrated genera of imperfect fungi. $3^{\text {rd }}$ Edition, Burgess Publishing co. 273PP.

Bweimer, J.L. And Harter, L.L. 1921. Woundcork formation in the sweet potato. $J$. Agri. Res., Vol. XXI, No. 9 Washington, D. C Aug. 1, 1921, Key No. G-243.

Coursey, D.G. and Booth, R.H. 1972. The post- 
harvest phytopathology of perishable tropical produce. Rev. Pl. Pathol., 51: 751-765.

Deka, B.C., Choudry, S., Bhattacharya, A., Begum, K.H. and Neog, M. 2006. Postharvest treatments for shelf life extension of banana under different storage environments. IV International Conference on managing in chains. The integrated view on fruits and vegetables quality. ISHS ActaHorticulturae, 712: 110-116.

Domsch, K.H., Gams, W., Anderson, T.H. 1993. Compendium of Soil Fungi. Academic Press, London, 1993; p. 860.

Ellis, M.B. 1971. Dematiaceous Hyphomycetes, Common wealth Mycological Institute Kew, Surrey, UK. pp.607.

Ellis, M.B. 1976. More Dematiaceous Hyphomycetes CMI, Kew, Surrey, UK, pp.507

FAO. 1977. Analysis of of an FAO survey of "Post-harvest crop losses in developing countries". AGPP Misc, 27.

FAO. 2002. Production year Book, Vol. 54, FAO, Stat. Sec. 163, Food and Agric. Organization, united Nations, Rome.

FAO. 2011. Global food losses and waste: Extent, Causes and Prevention.

Gams, W., Hockstora, E.S., Aptroot, A. 1998. CBS course of Mycology. $4^{\text {th }}$ Ed. Central bureau voorschimmel cultures, Baan, The Netherlands.

Klich, M.A. 2002. Identification of common Aspergillus species. CBS, Utrecht. p. 116.

Madhukar, J., Reddy, B. 1991. Biochemical changes in guava fruits due to infection by two pathogenic fungi. Indian J. Mycol. Pl. Pathol., 21: 179-182.

Moubasher, A.H. 1993. Soil Fungi in Quatar and other Arab countries. The centre for scientific and Applied Research, University of Quatar.

Nagamani, A., Kunwar, I.K. and Manoharachary, C. 2006. Hand Book of Soil Fungi. I. K. International Pvt. Ltd.

Obetta, S.E., Nwakonobi T.U. and Adikwu, O.A. 2011. Microbial Effects on Selected Stored Fruits and Vegetables under Ambient Conditions in Makurdi, Benue State, Nigeria. Res. J. Appl. Sci. Engi. Technol., 3(5): 393-398.

Odebode, A.C., Unachulwu, N.E. 1997. Effect of storage environment on carrot root rot and biochemical changes during storage. Z Lebensm Unters Forsch A., 205: $277-$ 281.

Pitt, J.I. and Hocking, A.D. 1997. Fungi and food spoilage $2^{\text {nd }}$ edition. Blackie Academic and professional press, Cambridge, U. K. 593PP.

Robinson, R.K. 1983. The vanishing harvest; a study of food and its conservation. Oxford Univ. Press. U.K.

Samson, R.A. and Varga, J. 2007. Aspergillus systematic in the genomic era. CBS Fungal Biodiversity Centre, Utrecht, p. 206.

Sarkar, S. 2009. Post-harvest diseases of Banana and their management. Ph.D thesis, Kakatiya University, Warangal, A. P., India.

Thakur, D.P. 1966. I. Survey of Delhi market for fungal diseases of fruits and vegetables. II. Studies on Rhizopus rot of some fruits and vegetables and its control. Ph.D. Thesis, IAIRI.

Usharani. 1982. Ph.D. thesis on pre and postharvest diseases of some underground vegetables. Dept. of Botany, Osmania University, Hyderabad, Telangana, India.

\section{How to cite this article:}

Brunda Devi, K., Pavan Kumar Pindi, D.S.R. Rajender Singh and Bhadraiah, B. 2016. Study on Fungi Associated with Tuber Vegetables during Storage in Markets of Telangana State, India. Int.J.Curr.Microbiol.App.Sci. 5(12): 919-929.

doi: http://dx.doi.org/10.20546/ijcmas.2016.512.100 